\title{
PERIODIC STRUCTURES OF GREAT LAKES LEVELS USING WAVELET ANALYSIS
}

\author{
TANER M. CENGIZ \\ Namik Kemal University, Çorlu Mühendislik Faculties, Civil Engineering Department, Hydraulics Division, 59860, \\ Çorlu/ TEKIRDAG; Mailto: tcengiz@nku.edu.tr
}

\begin{abstract}
The recently advanced approach of wavelet transforms is applied to the analysis of lake levels. The aim of this study is to investigate the variability of lake levels in four lakes in the Great Lakes region where the method of continuous wavelet transform and global spectra are used. The analysis of lake-level variations in the time-scale domain incorporates the method of continuous wavelet transform and the global spectrum. Four lake levels, Lake Erie, Lake Michigan, Lake Ontario, and Lake Superior in the Great Lakes region were selected for the analysis. Monthly lake level records at selected locations were analyzed by wavelet transform for the period 1919 to 2004. The periodic structures of the Great Lakes levels revealed a spectrum between the 1-year and 43-year scale level. It is found that major lake levels periodicities are generally the annual cycle. Lake Michigan levels show different periodicities from Lake Erie and Lake Superior and Lake Ontario levels. Lake Michigan showed generally long-term (more than 10 years) periodicities. It was shown that the Michigan Lake shows much stronger influences of inter-annual atmospheric variability than the other three lakes. The other result was that some interesting correlations between global spectrums of the lake levels from the same climatic region were found.
\end{abstract}

KEY WORDS: Wavelet Transform, Global Spectrum, Periodic Structure, Lake Level, Great Lakes.

Taner M. Cengiz: PERIODICKÁ ŠTRUKTÚRA HLADÍN VELKÝCH JAZIER (GREAT LAKES) URČENÁ POMOCOU VLNOVEJ ANALÝZY. J. Hydrol. Hydromech., 59, 2011, 1; 38 lit., 4 obr., 3 tab.

Nedávno zdokonalená metóda vlnovej transformácie je aplikovaná na analýzu úrovne hladín jazier. Táto práca obsahuje výsledky štúdia variability úrovne hladín štyroch jazier v regióne Vel'kých jazier, s využitím metódy kontinuálnej vlnovej transformácie a globálneho spektra. Boli študované variácie hladín vybraných Vel'kých jazier v závislosti od času. $\mathrm{Na}$ analýzu úrovne hladín boli vybrané štyri jazerá: Lake Erie, Lake Michigan, Lake Ontario, a Lake Superior v regióne Great Lakes. Mesačné chody úrovne hladín za obdobie rokov 1919 až 2004 boli študované vlnovou analýzou. Periodická štruktúra hladín Great Lakes bola zistená v spektre medzi 1 a 43 rokmi. Bolo zistené, že hlavnou periódou úrovne hladín je ročný cyklus. Na rozdiel od jazier Lake Erie, Lake Superior a Lake Ontario úrovne hladín Lake Michigan majú inú periodicitu. Lake Michigan má vo všeobecnosti dlhodobú (viac ako 10-ročnú) periodicitu. Je ukázané, že jazero Michigan reaguje na medziročnú variabilitu vlastností atmosféry výraznejšie ako ostatné tri jazerá. Ďalšími výsledkami analýzy sú niektoré zaujímavé korelácie medzi všeobecným spektrom úrovne hladín jazier z identického klimatického regiónu.

KLÚČOVÉ SLOVÁ: vlnová transformácia, globálne spektrum, periodická štruktúra, úroveň hladiny, Vel'ké jazerá.

\section{Introduction}

The Great Lakes are a dominant feature in central eastern portion of the North American continent. $18 \%$ of the world's freshwater supply resides in the Great Lakes totaling $22684 \mathrm{~km}^{3}$ of water in a drainage basin $244000 \mathrm{~km}^{2}$ (Fig. 1).

Hydrologic variables tend to reflect climatic change and can be of help in understanding the relations between hydrology and climate (Von
Storch, and Navarra, 1995). One of the significant indicators of climatic change is lake level variation. Water level fluctuations of lakes are related to regional and global scale climate changes, and reflect variations in evaporation and precipitation over the lake area and its catchment area.

Lake levels in different regions of the world have been measured using a range of methods since the beginning of the $20^{\text {th }}$ century. In one recent study, Mercier et al., (2002) presented results of lake level 


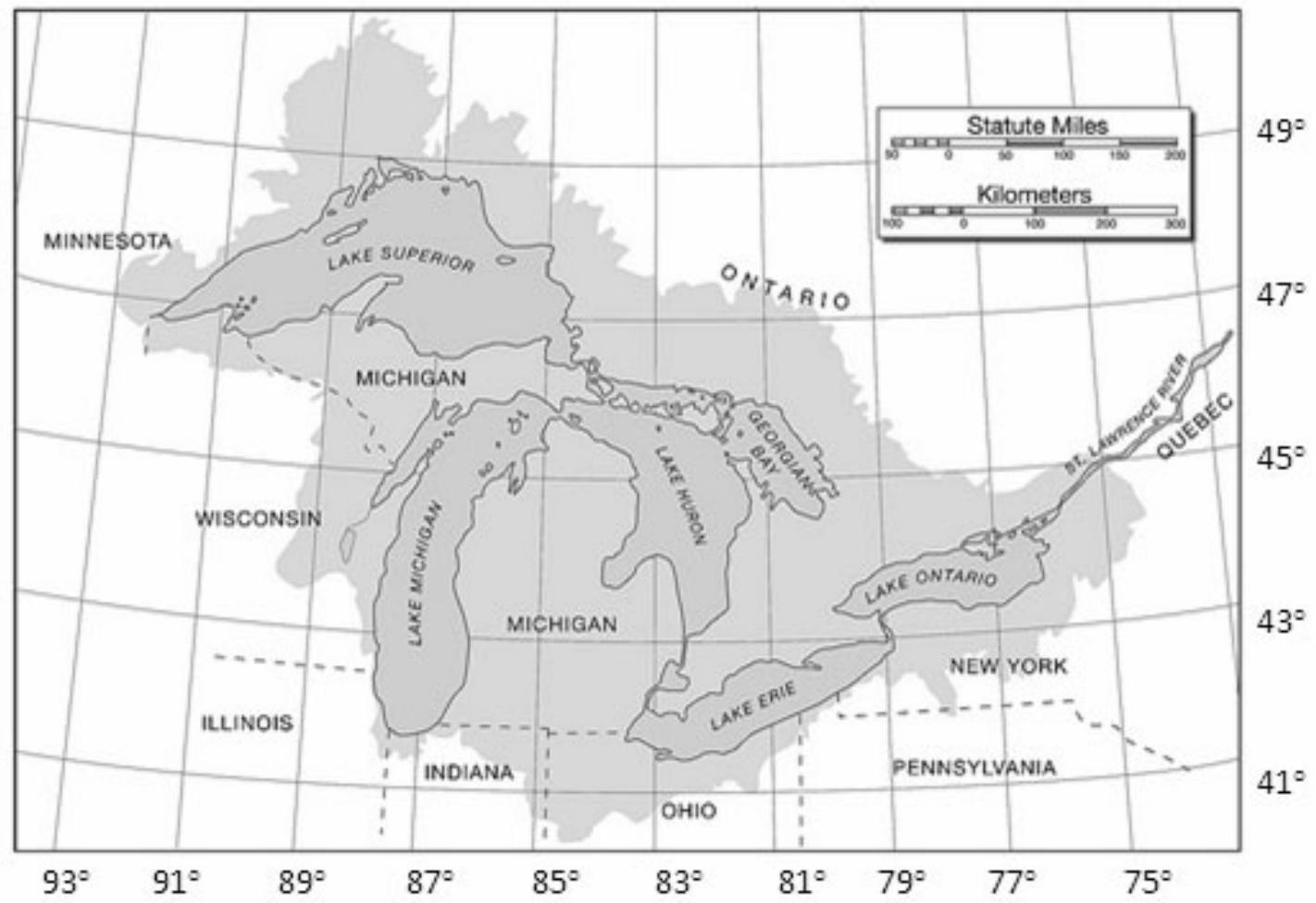

Fig. 1. A map of the Great Lakes regions.

variations of 12 African lakes based on 7 years of Topex/Poseidon (T/P) altimetry data. Lake levels have been continuously affected by hydrological, meteorological and anthropogenic conditions. Several geophysical processes may affect the level fluctuations of lakes, either locally or globally.

Regarding the interannual level fluctuations of lakes, all these phenomena are usually considered as negligible since their amplitudes are generally less than ten centimeters and thus only slightly increase the scatter of lake level time series. In addition, most of these local processes average to zero at the scale of the whole lake when a mean lake level height is computed, assuming homogeneous sampling of the surface patterns is performed. For this complex nature of lake levels, powerful tools for analysis are needed. Since the wavelet transform method is an proper tool for analyzing nonstationary series, it has had an explosion of interest over the last few years in water resources. One of the first wavelet transform studies in water resources was performed by Kumar and FoufoulaGeorgiou (1993). In their study, rainfall records were firstly decomposed by using the multiresolution technique, then components were ana- lyzed. Satellite images of rainfall events were also analyzed by using same technique. Venugopal and Foufoula-Georgio (1996) performed another study in 1996 (Venugopal and Foufoula-Georgiou (1996)). This study dealt with time-frequency-scale features of high-resolution temporal rainfall. In their study, hourly precipitation records were analyzed by using wavelet packets. The best representation, such as the maximum information with the minimum coefficients, was obtained for a signal. The short-lived structures and their associated frequencies and as well as energy were examined in the study.

Many investigations of hydrological multivariate phenomena in a region are analyzed using wavelet transform hydrological. For example, Labat et al. (2000) studied rainfall rates and runoffs measured at the outlet of karstic springs located in Pyrénées Mountains and the Larzac plateau. In their study, wavelet transform was proposed in order to characterize and to clarify the temporal variability of the relationship between two processes. In the study of Gaucherel (2002), a standard statistical analysis and wavelet analysis of the French Guyana flow rates were performed. The standard and wavelet 
statistics were then classified over the watershed set. Characterization of the different basins from their flow rate curves was carried out using the standard wavelet transform. Lafreniére and Sharp (2003) investigated the runoff regimes of two adjacent alpine catchments (one largely glacier covered, and one virtually ice free), to asses the relationship to meteorological forcing, and their inter-annual variability over an ENSO cycle. Wavelet analyses of temperature, discharge, and rainfall time series are used to compare the seasonal and inter-annual variability of hydrological processes operating in the two catchments in four consecutive summers. In the study of Lucero and Rozas (2002), it was proposed to identify the changes in seasonal number of rainy days and daily rainfall amount taking place during observed climate variability in annual rainfall. An analysis of the time series of annual rainfall using integral wavelet transform allowed them to identify the sub-decadal and inter decadal characteristics of the climate change. Smith et al. (1998) analyzed 91 daily and hourly streamflow series by using discrete wavelet transform. Streamflow series were decomposed to their components and energy variations of the components were used for streamflow classification by considering the regional climate conditions. For climate analysis and predictions, either wavelet spectrum or global spectrum are widely used for climatic studies in last five years. Qian et al. (2004) investigated potential contribution of maximum subsurface temperature anomalies to the climate variability. Maximum subsurface temperature anomalies periods of mode series were performed from a global wavelet spectral analysis. Pisoft et al. (2004) analyzed cycles and trends in the Czech temperature series. They used periodicities and oscillations from the series wavelet power spectra and global wavelet spectra. Benner (1999) examined the central England daily temperature record from 1659 to 1997, both for its own variability and for its relationship to other climatic records. He used four spectral methods which include global wavelet spectrum. Mwale et al. (2004) calculated variability and predictability of seasonal rainfall of central southern Africa for 1950-1994.

Although many studies related to wavelet transform have been performed, studies of lake level variation analysis using wavelet transform are limited. Analysis of wind-induced thermocline oscillations of Lake Tanganyika was performed by morlet wavelet (Naithani et al., 2003). In the study, wavelet transform was used to study the evolution of periods of thermocline oscillations with depth in the time series of observations and along the length of the lake using model simulations. In the study of Golitsyn at al. (2002), Ladoga and Onega hydrological regimes and their variations were analyzed. Based on the analysis, including wavelet, of the longer series of long-term variations in the Ladoga water level, it was found that the spectral structure pronouncedly changed in the period from 1859 to 1995. Liu and Hawley (2002), investigated grouping characteristics in near shore Great Lakes. Hwang et al. (2005) documented the wavelet spectra revealing annual and interannual variations of six Chinese lake level series. At the interannual time scale, the lake levels of Hulun, Bosten and Nganzi were correlated with precipitation and ENSO. All these lakes responded to the 1977-1998 El Nino episode and their wavelet spectra showed significant oscillations at different time-scale.

Research on Great Lakes water levels has focused primarily on annual variations (Quinn, 1981; Bishop, 1990), connections with climate variability (Changnon, 1987; Rodionov, 1994; Brinkmann, 1985), monthly changes in lake level (Quinn et al. 1979; Brinkmann, 1983; Quinn and Guerra, 1986; Brinkmann, 2000). Although many of these studies note significant interannual and decadal variability in Great Lakes water levels (Lenters, 2001).

Wavelet spectra of these lake level time series show oscillations at different timescales. Especially, the global spectrums of the continuous wavelet transform analyses results clearly represents the climatic characterization of the region analyzed. The time intervals of periodic events and correlations between global spectrums of the lake levels from the same climatic region were also determined. In addition, one of the useful outcomes of this study is to describe the time intervals of periodic events.

In the present study, it is investigated that how lake levels fluctuations vary in the time scale domain. The main purpose is to identify structures of lake level variations in the time domain. Another objective of this study is to assess the relations between the periodic structures of each lake and to define the similarity of periodicities for the lake levels. For these purpose, both wavelet continuous and global spectrums are used. 


\section{Methods}

\subsection{Method of wavelet analysis}

In recent years, there has been increasing interest in the use of wavelet analysis in a wide range of field in science and engineering (Polikar, 1999). Wavelet Transform (WT) analysis, developed during the last two decades, appears to be a more effective tool than the Fourier transform (FT) in examining nonstationary time series and transient phenomena, such as hydrological processes (Kü̈çük and Aağiralioğlu, 2003). For climate analysis and global spectrum methods have been widely implemented in the last 5 years (Küçük and Aağiralioğlu, 2006). Continuous and global wavelet spectra of streamflow were used in studies of climate classification (Smith et al.,1998; Saco and Kumar, 2000). In broad terms, wavelet decomposition provides a way of analyzing a signal both in time and in frequency (Daubechies, 1990).

Instead of results presented in a plot of energy versus frequency for energy spectrum in Fourier transform (FT) and fast Fourier transform (FFT), the wavelet spectrum is three dimensional and energy appears as contour lines plotted in the timefrequency domain. This provides an ideal opportunity to examine the process of energy variations where and when the hydrological events occur (Liu, 2000). The wavelet spectrum based on continuous WT (hereafter abbreviated as CWT), is a naturel extension of the convential Fourier spectrum analysis which are commonly used in hydroclimatological time series analysis (Drago and Boxall, 2002).

Assuming a continuous time series $x(t)$, $t \in[\infty,-\infty]$, a wavelet function $\psi(\eta)$ that depends on a nondimensional time parameter $\eta$ can be written as

$\psi(\eta)=\psi(\tau, s)=s^{-1 / 2} \psi\left(\frac{t-\tau}{s}\right)$,

where $t$ denotes time, $\tau$ - the time step in which the window function is iterared, $s \in[0, \infty]$ for the wavelet scale. $\psi(\eta)$ must have zero mean and be localized in both time and Fourier space (Meyer, 1993). The CWT is expressed by the convolution of $x(t)$ with a scaled and translated $\psi(\eta)$,

$W(\tau, s)=s^{-1 / 2} \int_{-\infty}^{+\infty} x(t) \psi^{*}\left(\frac{t-\tau}{s}\right) \mathrm{d} t$ where * denotes complex conjugate. By changing varying both $s$ and $\tau$ values gradually, one can construct a two-dimensional picture of wavelet power, $\left|W_{t}(s)\right|^{2}$ indicating the frequency (or scale) of peaks in the spectrum of $x(t)$, and how these peaks change with time.

During computation the wavelet is shifted smoothly over the full domain of the analysed signal so that the CWT is also continuous in terms of shifting (Drago and Boxall, 2002).

In Fourier analysis, a signal is broken up into smooth sinusoids of unlimited duration. Similarly, wavelet analysis consists in the breaking up of a signal into wavelets which are waveforms of effectively limited duration and zero mean, but which may be irregular and asymmetric. Wavelet analysis is essentially a windowing technique with variablesized regions. The analysis consists in shifting forward the wavelet in steps along the full signal and generating at each step a wavelet coefficient that measures the level of correlation of the wavelet to the signal in each section. When the full series is covered, a set of wavelet coefficients that has the same consistency in time is generated as that of the original signal. The variation in the coefficients indicates the changing level of similarity of the wavelet with the signal in time. This process is repeated with scaled (stretched) versions of the wavelet so that sets of wavelet coefficients at different scales are generated. This results in a set (at each scale) of series of wavelet coefficients that are a function of time. Wavelet analysis, thus, gives a time-scale view of a signal and provides a method of expressing natural phenomena by utilizing their very rudimentary multi-fractal basis.

The lower scales refer to the compressed wavelet and are able to follow the rapidly changing details or high frequency component of the signal. The higher scales are composed from the stretched version of a wavelet and the corresponding coefficients represent the slowly changing coarse features or low-frequency component.

\subsection{Global wavelet spectrum}

If a vertical slice through a wavelet plot is a measure of the local spectrum, then the timeaveraged wavelet spectrum over all certain period or all the local wavelet spectra is

$\overline{W^{2}}(s)=\frac{1}{T} \sum_{t=0}^{T-1}\left|W_{t}(s)\right|^{2}$, 
where $T$ - number of points in the time series. The time-averaged wavelet spectrum is generally called the global wavelet spectrum (Torrence and Compo, 1998). The smoothed Fourier spectrum approaches the global wavelet spectrum when the amount of necessary smoothing decreases with increasing scale. Hence, the global wavelet spectrum provides an unbiased and consistent estimation of the true power spectrum. This spectrum is a useful tool for non-stationary time series analysis. The global spectrum is compatible with a power (Fourier) spectrum. When, in a power (frequency) spectrum, spectral components are defined as frequency, periodic components are ordered according to period scales in a global wavelet spectrum. In addition, since a global spectrum is calculated by using a continuous spectrum, the starting and finishing time of the periodic components can be known.

\subsection{Application region and data}

The Great Lakes, is a group of five large freshwater lakes in central North America, interconnected by natural and artificial channels. From west to east they are Lake Superior, Lake Michigan, Lake Huron, Lake Erie and Lake Ontario. Water levels on the lakes vary over periods of several years by as much as $1 \mathrm{~m}$, and during storms lake levels may rise or fall as much as $2 \mathrm{~m}$, especially on Lake Erie, the shallowest of the Great Lakes. Longterm variations in lake levels are caused primarily by variations in precipitation. Lakes Superior and Ontario are the only lakes among the Great Lakes whose water levels are regulated for hydroelectricpower generation. Lakes Superior, Michigan, Huron, Erie and Ontario, along with the connecting rivers and channels, compose the Great Lakes Basin system, which is located along the eastern international boundary between Canada and the United States (Botts and Krushelnicki, 1995; Sellinger, 2001; Skinner, 2002). In general, the outflow from the Great Lakes is small in comparison to the large total volume of water. Less than one percent of the total volume of water is discharged annually into the Atlantic Ocean (Botts and Krushelnicki, 1995; Skinner, 2002; Kurth, 2002).

Water levels around the Great Lakes Basin have been measured since the 1840 s, and initial indications show lake level fluctuations occur on an average of 160 years, with sub-fluctuations on an average of 33 years. However, the amplitude of water level fluctuations has decreased significantly since the opening of the St. Lawrence Seaway in 1959.
Lake levels are determined by precipitation, upstream inflows, surface water runoff, evaporation, diversions and water-level regulation. A mass balance between the amount of water entering the watershed and the amount exiting the watershed shows the relationship of these variables on lake water levels. Climate conditions control the amount of precipitation and the rate of evaporation. These two factors are the primary factors influencing lake water levels. The lakes depend on a large influx of water from the surrounding areas over winter. When above-average precipitation combined with cool and cloudy weather occurs, the water levels rise. Conversely, long periods of below-average precipitation with warmer weather result in lower water levels. In addition, during the winter months, in the absence of an ice layer, water will evaporate out of the lakes (Gauthier, 1999; Kurth, 2002).

In general, there are three types of water-level fluctuations in the Great Lakes; short-term, seasonal, and long-term. Short-term fluctuations, ranging from a few hours to several days, are generally caused by storms, ice build-up, and excessive plant growth. Seasonal fluctuations happen yearly as the Great Lakes Basin experiences four distinct seasonal climates. Annual, or seasonal, variations in water levels are mainly due to differences between the volume of water gained during the summer months and the volume of water lost during the winter months. Long-term fluctuations occur over many years, and are mostly the result of atmospheric climate changes that affect precipitation and plate tectonic activity. Climate change is becoming more extreme, and that could lead to larger fluctuations in the lake levels (Gauthier, 1999). Historically, the lake levels hit extreme lows in the mid1920 s, the mid-1930s, and the mid-1960s. Record highs were recorded in the late-1870s, the late 1920 s, the early-1950s, the early-1970s, the mid1980s, and the mid-1990s (Gauthier, 1999; Botts and Krushelnicki, 1995).

Locations, areas and statistics of monthly averaged lake level record are seen at Tab. 1. The lake levels were recorded during the period of June 1919 - September 2004. Total sample length of the records is 1024 months. In this study the Great Lake levels time series provided on the internet site (http://www.lre.usace.army.mil/greatlakes/hh/great lakeswaterlevels/historicdata/). Lake levels time series are shown in Fig. 2. Correlation coefficients of the lakes levels between each other are seen in Tab. 2. Even though Lake Michigan has a big variance in the time series, Lake Superior has very 
$\mathrm{T}$ a $\mathrm{b} l \mathrm{e}$ 1. Location areas and statistics of monthly averaged lake-level records of the lakes.

\begin{tabular}{lcccc}
\hline Lake & $\begin{array}{c}\text { Lake surface area } \\
{\left[\mathrm{km}^{2}\right]}\end{array}$ & $\begin{array}{c}\text { Lake volume }^{2)} \\
{\left[\mathrm{km}^{3}\right]}\end{array}$ & Mean level ${ }^{3)}[\mathrm{meter}]$ & Standard dev. ${ }^{4)}$ \\
\hline Lake Erie & 25,657 & 483 & 174.14 & 0.37 \\
Lake Michigan & 57,750 & 4,920 & 176.45 & 0.40 \\
Lake Ontario & 18,960 & 1,640 & 74.75 & 0.35 \\
Lake Superior & 82,100 & 12,230 & 183.42 & 0.19 \\
\hline
\end{tabular}

$\mathrm{T}$ a b 1 e 2. Correlations coefficients of the lakes levels time series.

\begin{tabular}{lcccc}
\hline & Lake Erie & Lake Michigan & Lake Ontario & Lake Superior \\
\hline Lake Erie & 1 & 0.88 & 0.81 & 0.41 \\
Lake Michigan & 0.88 & 1 & 0.70 & 0.56 \\
Lake Ontario & 0.81 & 0.70 & 1 & 0.32 \\
Lake Superior & 0.41 & 0.56 & 0.32 & 1 \\
\hline
\end{tabular}

Coefficients are significant at the $95 \%$ significance level.

a)

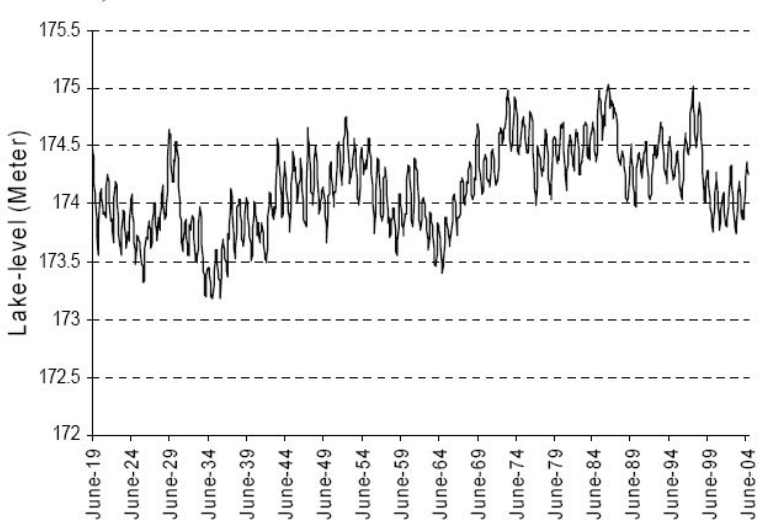

c)

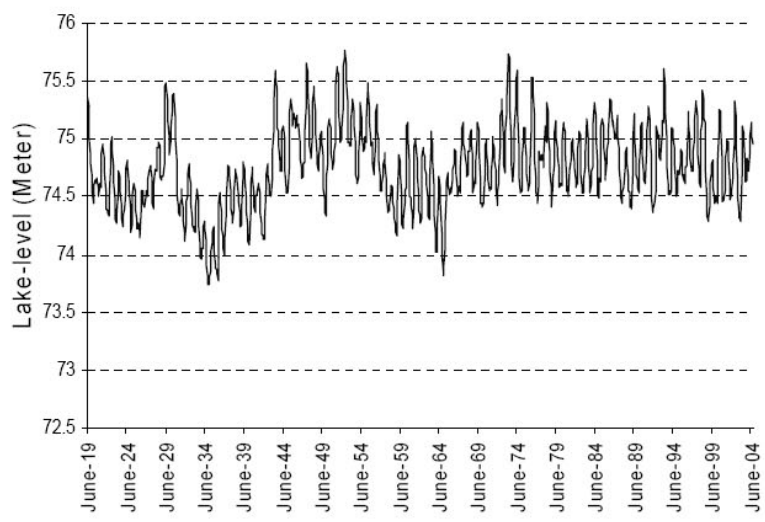

Time (Month) b)

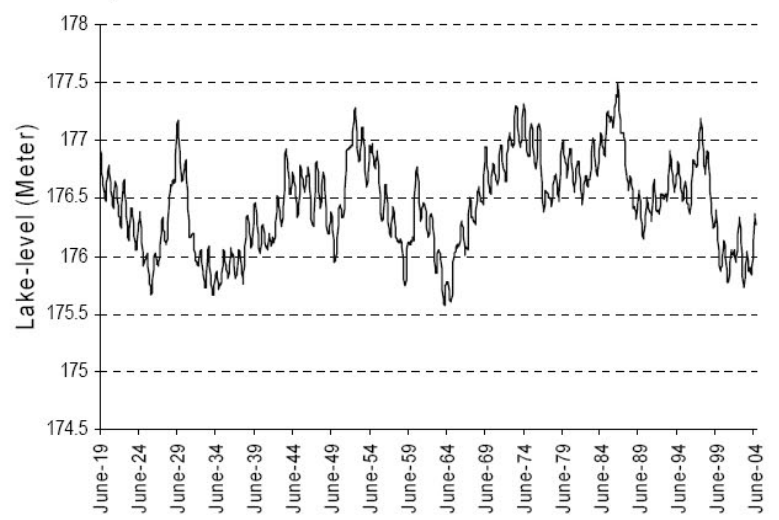

d)

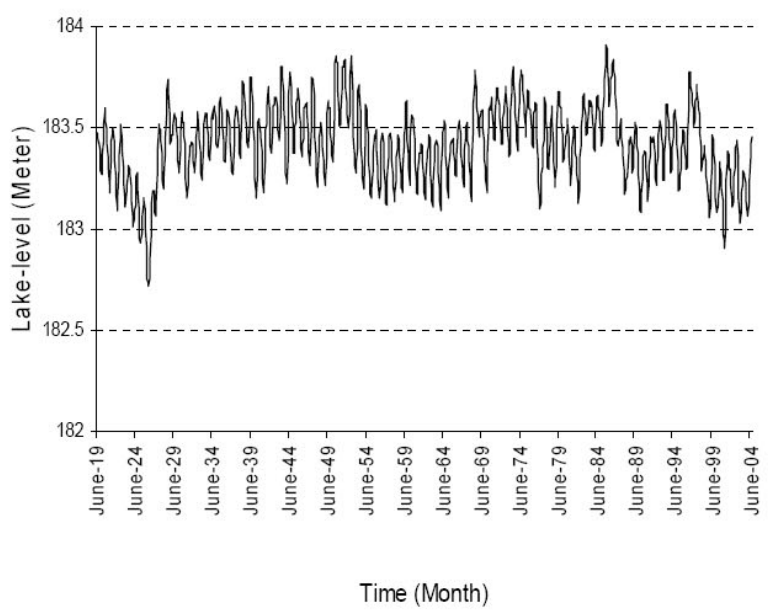

Fig. 2. Monthly averaged lake levels time series; a) Lake Erie, b) Lake Michigan c) Lake Ontario, d) Lake Superior.

small variance in the time series. In the correlations table (Tab. 2), the most interpretable correlation is between Lakes Erie and Michigan levels. Lakes
Erie and Ontario also have a high correlation however, Lakes Superior and Ontario have weak negative correlation. 


\subsection{Analyses of Great lakes-levels}

by continuous wavelet transform

Analysis of lake level records can provide significant information on past and future characteristics of lakes and the climate of regions and is important in water resources planning and management. Continuous wavelet transform can define periodic structures in averaged monthly lake level time series and can explain when periodic events start and finish. Transform of the time series was calculated and a three-dimension figure of the transform is shown in Fig. 3. Considering that the total measurement sample is 1024 , wavelet transform is performed as 10 scale-levels. The scale level number can be identified as the number of powers of 2 for the scale variable, thus the sample number is defined as 10 for wavelet transform. The basic function in this analysis is obtained by dilation and translation of a Morlet wavelet function. The Morlet function is as follows (Liu, 2000; Panizzo et al., 2002).

$\psi_{0}(t)=\pi^{-1 / 4}\left(\mathrm{e}^{-i a t}-\mathrm{e}^{-a^{2} / 2}\right) \mathrm{e}^{-t^{2} / 2}$.

Continuous wavelet spectrum results are shown in Fig. 3. The horizontal axes of the figures show the measurement time period. The vertical axes of the figures are logarithmic in order to identify periodic structures of the time series. Total lengths of vertical axis are 1024 months. High (low) variance of wavelet coefficients, defined in Eq. (2), is shown by light (dark) tones in Fig. 3. Light color means an increase of lake level. The 1024 months scales in figures of the continuous wavelet spectrums should be neglected, because of the length of record and cone influence. Power is reduced near the edges of the spectrum with the introduction of the zeros into the convolution. This zone of edge effects is known as the cone of influence.

Global wavelet spectrums of lake levels are also calculated (Fig. 4).

In the present study, the wavelet analysis is carried out by means of the "Rwave" module of the $\mathrm{R}$ software, which is a system for statistical computation and graphics (http://www.r-project.org).

A summary of the detected periodic components and their variations in lake levels is given below.

\section{Result and Discussions}

\section{Lake Erie levels}

The continuous wavelet transform is seen in Fig. 3a) and the global wavelet spectrum of the continuous spectrum is seen in Fig. 4a). The variation in Erie lake level contains semi-annual, annual and interannual periodic components. Main characteristic of continuous spectrums of Lake Erie level (Fig. 3a) is seen at 12 months scale (annual cycle or event). The annual cycle is seen through the whole measurement duration of the lake spectrum. In addition to periodic components of the monthly lake level at 512 months (43 years), 338 months (28 years), 256 months (21 years), 168 months (14 years), 104 months (9 years), 74 months (6 years) are seen in Fig. 4a). The energy of the annual periodicities of Lakes Erie is also high when compared to other periodicities. The semi-annual variation is weak but evident. It is interesting that the 512 months periodicity is a major periodic event for Lake Erie when compared to the other big periodicities. Historically, the lake levels hit extreme lows in mid-1920s, the mid-1930s, and the mid1960s. The annual cycle was interrupted in the mid1920s, the mid-1930s, and the mid-1960s in Lake Erie because of these dry periods. This dryness affects from 12 months events to 338 months events. In the continuous spectrum figure of Lake Erie, the amplitude of 12 months periodic components varies from year to year, and are largest over 1948-1952 and smallest over 1921-1926. The annual cycle is interrupted in 1926 and in 1987, because of dry periods. Besides annual cycle (12 months event), 512 months periodicities are seen over the whole record for continuous spectrum. The 338 month event is has a high magnitude from 1935 to 1985. Energy of 256 months periodicities are high over 1940-1980. The 128 months event is continuous between 1985 and 2004 with a high magnitude. Record highs were recorded in late 1920, the early-1950, the early-1970s, the mid1980, and the mid-1990s. Again, as these wet periods affect 12 month events to 338 months events, the water levels rose.

\section{Lake Michigan levels}

As for Erie lake level, the variation in Michigan lake level also contains semiannual, annual and interannual periodic components. Continuous wavelet transforms are seen in Fig. 3b) and global 
a)

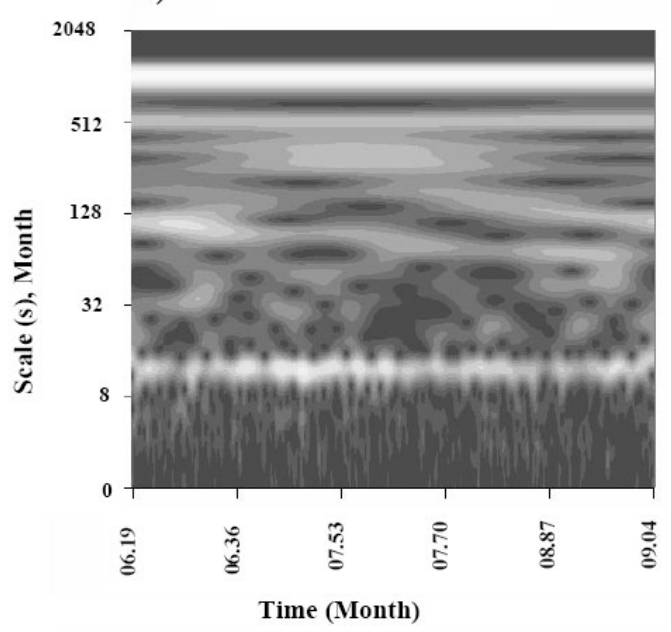

c)

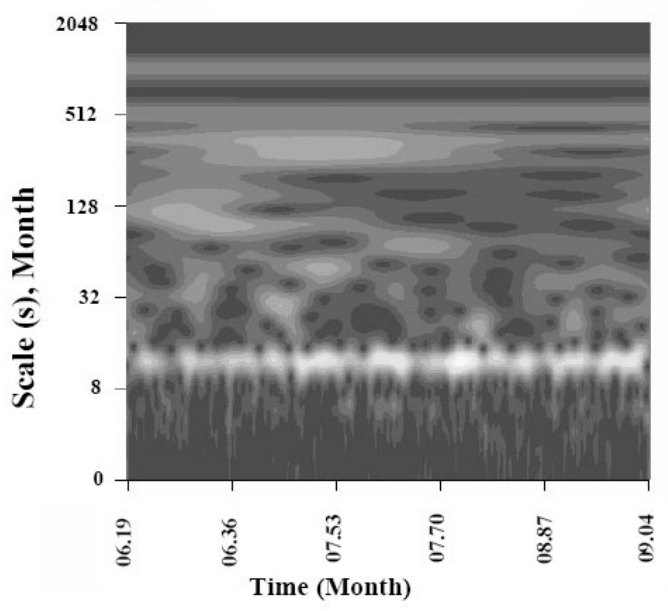

b)

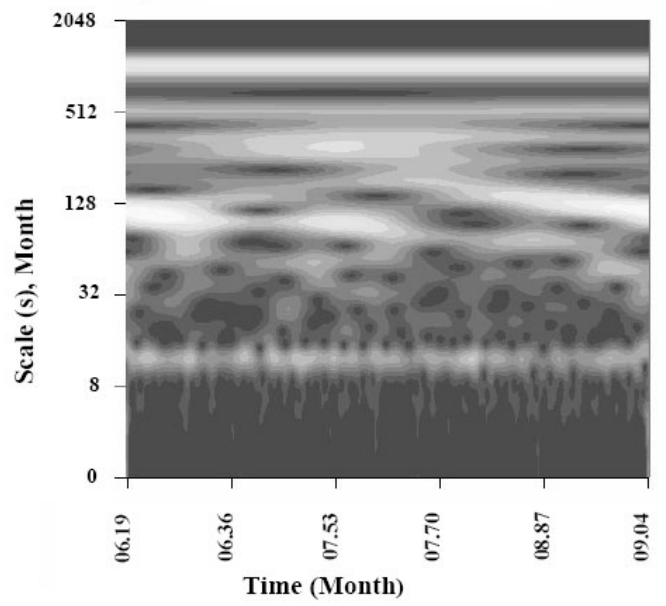

d)

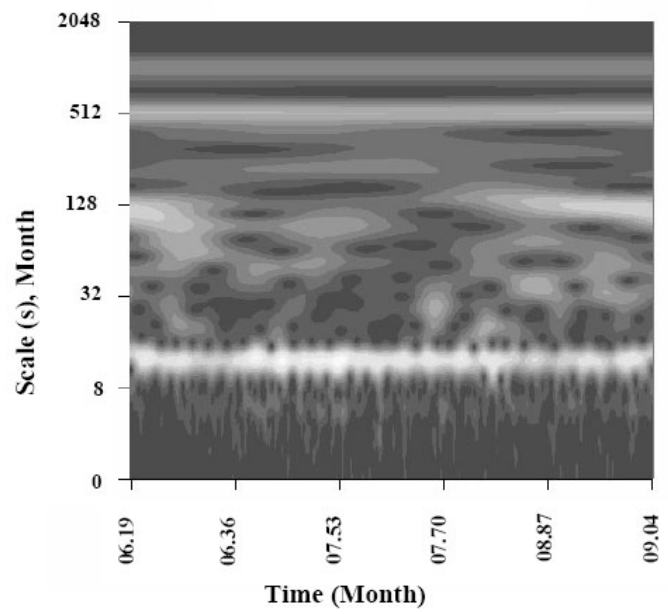

Fig. 3. Continuous wavelet spectrums of monthly averaged lake levels; a) Lake Erie, b) Lake Michigan c) Lake Ontario, d) Lake Superior.

wavelet spectrums of the continuous spectrum are seen in Fig. 4b). It is interesting that 104 month periodicity is the major periodic event for Lake Michigan. In Fig. 3b), the major periodicities are 104 and 128 months event, which was not expected. The annual cycle is seen through whole measurement duration of the lake spectrum. Considering Fig. 4b), the global spectrums of the lake levels include longer periodic events than 1 year, generally: the spectrum have 12 months (1 year), 52 months (4 years), 104 months (9 years), 128 months (11 years), 256 months (21 years), 512 months (43 years), 338 months (28 years) periodic events. The energy of the 104 and 128 months periodicities of Lake Michigan is also high when compared to other periodicities. In the continuous spectrum figure of Lake Ontario, the 104 months event is largest over 1920-1965 while 128 months event is largest over 1920-1936 and 1985-2004. In the continuous spectrum figure of Lake Michigan the 338 months event is continuous between 1928 and 1980, approximately with high magnitude. The annual cycle lows are found in 1926 and 1964 and 1934, while high is found in 1952 and 1974 and 1997.

\section{Lake Ontario levels}

The time-scale analysis indicated that the main periodicities of Lake Ontario series are 12 mounts events. The variation in Lake Ontario level contains semi-annual, annual and interannual periodic components. There is a weak semi-annual variation, but the pattern is irregular. The continuous wavelet transform figure is seen in Fig. 3c) and the global wavelet spectrums of the continuous spectrum are 

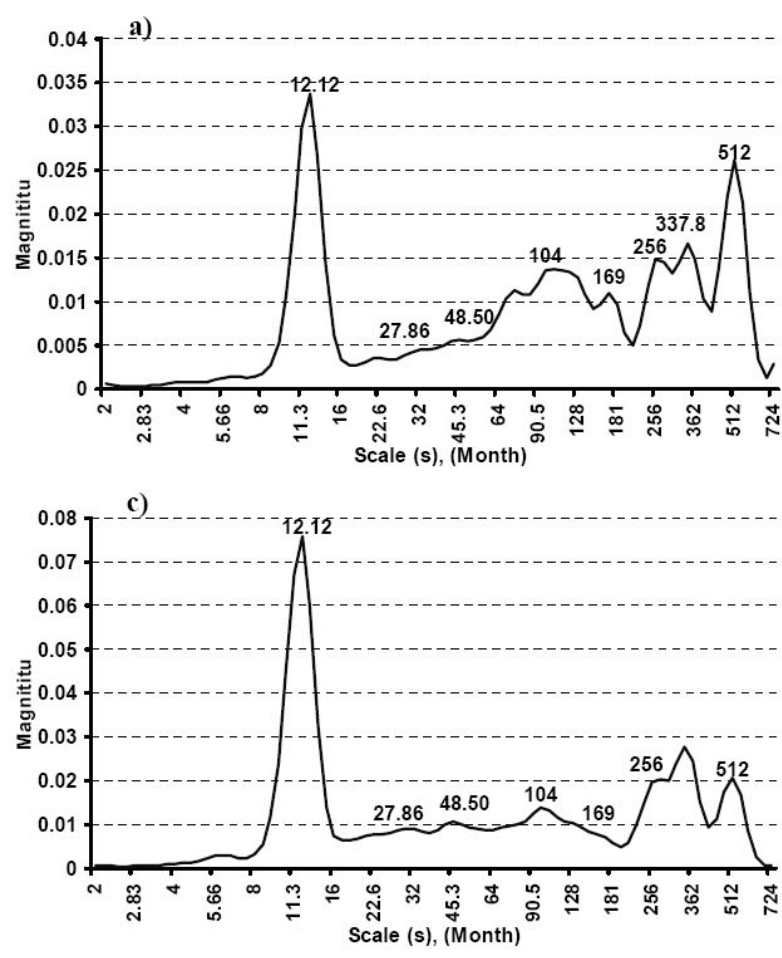
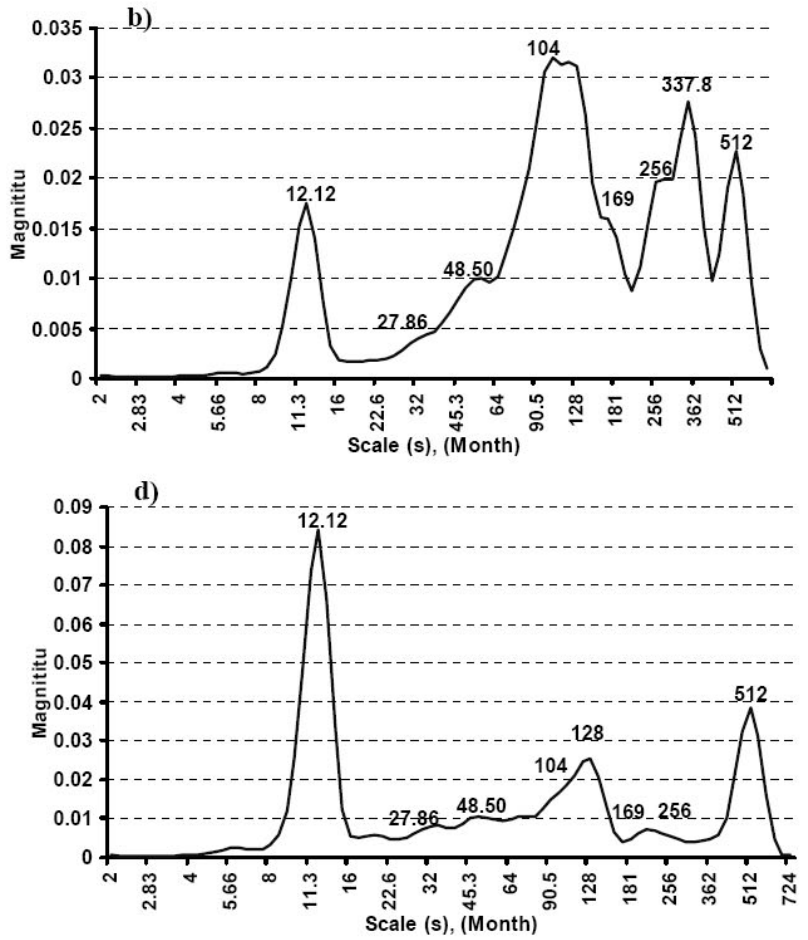

Fig. 4. Global wavelet spectrums of monthly averaged lake levels; a) Lake Erie, b) Lake Michigan, c) Lake Ontario, d) Lake Superior.

seen in Fig. 4c). In Fig. 3c), the major periodicity is the 12 month event, as expected; the annual cycle is seen through whole measurement duration of the lake spectrum. Considering Fig. 4c), the global spectrums of the lake levels include longer periodic events than 1 year, generally: the spectra have 12 months ( 1 year), 32 months ( 3 years), 104 months (9 years), 256 months (21 years), 338 months (28 years), 512 months (43 years) periodic events. The energy of the 12 months periodicities of Lakes Ontario is also high when compared to other periodicities. In the continuous spectrum figure of Lake Ontario, 256 month events are continuous between 1936 and 1966 with high magnitude. 338 months events and its near neighborhood (256-512 months events) are seen continuously in Lake Ontario. The 338 month events are continuous between 1920 and 1980 with high magnitude, too. The amplitude of the annual cycle component varies from year to year. The annual cycle lows, are found in 1926 and 1965, while the highs are found in 1973 and 1929.

\section{Lake Superior levels}

Semi annual, annual and interannual periodic components are found in the Lake Superior level variation. The semi-annual periodic components are weak in most years. The continuous wavelet transform is seen in Fig. 3d) and the global wavelet spectrums of the continuous spectrum are seen in Fig. 4d). Annual cycles are seen through whole measurement duration for Superior level spectrums. In addition to periodic components of the monthly lake level, 512 months (43 years), 208 months (17 years), 128 months (11 years), 45.3 months (3.8 years), 32 months (2.7 years), 6 months ( 0.5 years) periodic events are seen in Fig. 4d). The energy of the annual periodicities of the lakes Superior is also high when compared to other periodicities. In the continuous spectrum of Lake Superior, the 12 months event is of continuous high magnitude in 1950 and 1952 and 1943, because of wet periods while low magnitude is found in 1926 and 2001 which are dry years. At the 208 month timescale, there is a high peak in 1940-1970 and there are strong lows in 1985-2000. At the 128 month event, highs are found over 1920-1930 and 1980-2004. At the 512 month event, there is a weak peak over 1960-1980. In the mid-1920s, and the mid-1930s, and the mid-1960s, the lake levels extreme lows, the semi-annual and annual and 32-128 months events components are also weak. The lake levels 
highs were recorded in the late1920s, the early1950s, the early-1970s, the mid-1980s, and mid 1990s. These can be seen in the same time magnitude continuous wavelet spectrum of Lake Superior annual and interannualy periodic components are high magnitude while 12,128 and 208 months events. The 32 months event is continuous between 1967 and 1970 with high magnitude in the continuous spectrum. However, none of them is continuously seen in the figures; they are interrupted at different time periods. Besides the annual cycle (12 months event), 512 months periodicities are seen over the whole record duration for continuous spectrum.

\section{Correlation coefficient of the global spectrums}

A correlation coefficient matrix for the global spectrums of monthly series is seen in Tab. 3. It was expected that Lake Erie, Lake Michigan, Lake Ontario and Lake Superior should be in appropriate according to the global spectrums. Although Lake Superior and Lake Ontario have strong correlations, Lakes Ontario and Michigan have weak correlation according to the global spectrums correlation. It is interesting that some periodic events, in particular, the lake levels of Superior, Ontario and Erie, are correlated with each other. Some correlation coefficients between the global spectrum series of lakes decreased such as Lakes Superior-Michigan and Lakes Ontario-Michigan. These are evidence of long-term events in the lake levels. On the contrary some correlation coefficients increased such as Lake Superior-Ontario. However, the correlation coefficient of the global wavelet spectrums between Lakes Superior and Ontario (0.89) is higher than the correlation coefficients of the global wavelet spectrums between Lakes Superior and Michigan (0.39). Superior-Erie and Michigan-Erie global spectrum correlation values are 0.54 and 0.73 , respectively.

$\mathrm{T}$ a b 1 e 3. Correlation coefficients matrix of the global spectrums series.

\begin{tabular}{lcccc}
\hline & Lake Erie & Lake Michigan & Lake Ontario & Lake Superior \\
\hline Lake Erie & 1 & 0.73 & 0.56 & 0.54 \\
Lake Michigan & 0.73 & 1 & 0.39 & 0.38 \\
Lake Ontario & 0.56 & 0.39 & 1 & 0.89 \\
Lake Superior & 0.54 & 0.38 & 0.89 & 1 \\
\hline
\end{tabular}

Coefficients are significant at the $95 \%$ significance level.

\section{Conclusions}

This study is to investigate the variability of lake levels in four lakes scattered across Great lake region using the method of continuous wavelet transform and global spectra. The results of this study reveal significant periodicities of Great Lakes water levels over the period 1919 to 2004 . Wavelet spectra indicate annual and interannual variations of these lake levels. Continuous and global spectrums of monthly average lake level were evaluated. Using monthly time series, periodic structures could be detected in the Great Lakes levels. Higher scale events were also major in both continuous and global spectrums of monthly averaged series. Continuous wavelet transform and global wavelet spectrum of the four Great Lakes levels time series exhibited oscillations at different timescales.

It is found that major lake levels periodicities are generally the annual cycle. Annual cycle events were generally continuous in the continuous spectrum, except for some interruptions. The significant annual cycle of lake levels are the evidence of four distinct seasons in The Great Lakes region. Periodicities smaller than annual cycles could not be easily detected. Lake levels show a change in dominant interannual scales (11 to 43 years) to interdecadal time scales (10 to 40 years). 104, 128, 256, 338 and 512 months events are continuous in the continuous spectrums, including the annual cycle. Lakes Erie, Ontario and Superior have also higher magnitude values than Lake Michigan according to annual periodicities in the global spectrum of lake levels. On the other hand, it is interesting that 104 and 128 months events are major for Lake Michigan when compared with the annual cycle. Besides the 512 months event, 338 months periodicities are seen for the whole record duration for each continuous spectrum, except for Lake Superior. It is found also that longer periodic events as observed in Lake Erie, Lake Michigan and partially Lake Superior are major events. Wavelet transforms detected the start and finish of periodic events. In the present study, some lakes in the same 
climatic conditions indicated similar characteristics in long-term analysis. For example, Lakes Superior, Michigan and Erie are located in close proximity to each other and are affected by a common climate. Lake Superior and Lake Ontario and Lake Erie behave similar to each other, but rather differently from Lake Michigan. The similarity of the global spectrums could be caused by factors such as altitudes of lakes and physical characteristics of the basins. Since lake levels are highly affected by evaporation, in situ conditions, soil type, reservoir capacity, unnatural effects etc., analysis should consider other effects. Physical characteristics of the lake basins play one of the most important roles on lake levels. All the Great Lakes levels higher scale periodic events, mainly 338 events and near neighborhood events were gradually decreased in the continuous wavelet spectrums by the time. Consequently, the time-scale analysis of lake-levels in the Great Lakes clearly indicated the effects of the long periodic events. These interannaul variations possibly the result of long term climate change such as El Nino Southern Oscillation, the North Atlantic Oscillation and global warming. As a first attempt, I have shown the feasibility and usefulness of using the wavelet transform approach. The analysis presented here will be useful in studies of lake levels time series, and the addition of statistical significance tests will improve the quantitative nature of wavelet analysis.

Acknowledgments. I am grateful for the constructive comments from two anonymous reviewers. The author wish to thank to Dr. Murat Küçük who had lost his life in a heartbreaking traffic accident, for helpful comments. May God bless his soul. I would like to express my deepest gratitude to Dr. Geoff Kite.

\section{REFERENCES}

BENNER C.T., 1999: Center England temperatures: LongTerm Variability and Teleconnections. Int. J. Climatol.,19, pp. 391-403.

BISHOP C.T., 1990: Historical variation of water levels in Lakes Erie and Michigan-Huron, J. Great Lakes Res., 16, 3 , pp. 406-425.

BRINKMANN W.A.R., 2000: Causes of variability in monthly Great Lakes water supplies and lake levels. Climate Research, 15, pp. 151-160.

BOTTS L. and KRUSHELNICKI B., 1995: Great Lakes Atlas. 3rd Edition, produced by Government of Canada (Toronto, Ontario) and U.S. Environmental Protection Agency, Great Lakes National Program Office -Chicago, IL.

CHANGNON S.A., 1987: Climate fluctuations and record high levels of Lake Michigan. Bulletin of the American Meteorological Society, 68, 11, pp. 1394-1402.
DAUBECHIES I., 1990: The wavelet transform, timefrequency localization and signal analysis. IEEE Transactions on Information Theory, 36, 5, pp. 961-1005.

DRAGO A.F., BOXALL S.R., 2002: Use of the wavelet transform on hydro-meteorological data. Physics and Chemistry of the Earth, 27, pp. 1387-1399.

GAUCHEREL C., 2002: Use of wavelet transform for temporal characterisation of remote watersheds. J. Hydrol., 269, pp. 101-121.

GAUTHIER, R., 1999: Living with the Lakes - Understanding and Adapting to the Great Lakes Water Level Changes. U.S. Army Corps of Engineers and the Great Lakes Commission.

GOLITSYN G.S., EFIMOVA L.K., MOKHOW I. I., RUMYANTSEV, SOMOVA N.G., KHON V.Ch., 2002: Ladoga and Onega Hydrological Regimes and Their Variations. Wat. Resour., 29, pp. 168-173.

KUMAR P., FOUFOULA-GEORGIOU E., 1993: A multicomponent decomposition of spatial rainfall fields 1 . Segregation of large- and small-scale features using wavelet transforms. Wat. Resour. Res., 29, 8, pp. 2515-2532.

KURTH, J., 2002: Shrinking Great Lakes threaten Michigan way of life. The Detroit News. January 24, 2002.

KÜÇÜKK M., AĞIRALIOĞLU N., 2003: Stationary and nonstationary time series analysis aided by short time Fourier transform. III. National Atmosphere Symposium, March, 19-21, Istanbul, pp. 218-225.

KÜÇÜK M., AĞIRALIOĞLU N., 2006: Wavelet regression technique for streamflow prediction. J. Appl. Statistic, 33, 9, pp. 943-960.

LABAT D., ABABOU R., MANGIN A., 2000 : Rainfallrunoff relations for karstic springs. Part II: continuous wavelet and discrete orthogonal multiresolution analyses. J. Hydrol., 238, pp. 149-178.

LAFRENIÉRE M., SHARP M., 2003: Wavelet Analysis of inter-annual variability in the runoff regimes of glacial and nival stream catchments, Bow Lake, Alberta. Hydrolog. Processes, 17, pp. 1093-1118.

LENTERS J.D., 2001: Long-Term Trends in the Seasonal Cycle of Great Lakes Water Levels, J. Great Lakes Res., 27, 3, pp. 342-353.

LIU P.C., 2000: Wave grouping characteristics in nearshore Great Lakes. Ocean Engng., 27, pp. 1221-1230.

LIU P. C., and HAWLEY N., 2002: Wave grouping characteristics in nearshore Great Lakes II. Ocean Engng., 29, pp. $1415-1425$.

LUCERO O.A., ROZAS D., 2002: Characteristics of aggregation of daily rainfall in a middle-latitudes region during a climate variability in annual rainfall amount. Atmospheric Res., 61, pp. 35-48.

MERCIER F., CAZENAVE A., MAHEU. C., 2002: Interannual lake level fluctuations (1993-1999) in Africa from Topex/Poseidon: connections with ocean-atmosphere interactions over the Indian Ocean. Global and Planetary Changes, 32, pp. 141-163.

MEYER Y., 1993: Wavelets Algorithms \& Applications. Society for Industrial and Applied Mathematics, Philadelphia.

MWALE D., GAN T.Y, SHEN S.P., 2004: A New Analysis of Variability and Predictability of seasonal rainfall of Central Southern Africa for 1950-94. Int. J. Climatol., 24, pp.1509$-1530$.

NAITHANI J., DELEERSNIJDER, PLISNIER P.D., 2003: Analysis of Wind-Induced Thermocline Oscillations of Lake Tanganyika. Fluid Mechanics, 3, pp. 23-39. 
PANIZZO A., BELLOTTI G., GIROLAMO P.D., 2002: Application of wavelet transform analysis to landslide generated waves. Coastal Engng., 44, pp. 321-338.

PISOFT P., KALVOVÁ J., BRÁZDIL R., 2004: Cycles and trends in Czech temperature series using wavelet transforms. Int. J. Climatol., 24, 1661-1670.

POLIKAR R., 1999: The story of wavelets, in physics and modern topics in mechanical and electrical engineering. pp. 192-197. Mastorakis, N. World Scientific and Eng. Society Press.

SACO P., KUMAR P., 2000: Coherent modes in multiscale variability of streamflow over the United States. Wat. Resour. Res., 36, 4, pp. 1049-1067.

SELLINGER, C., 2001: Great Lakes Water Levels. Website Article - Great Lakes Environmental Research Laboratory 2205 Commonwealth Blvd., Ann Arbor, MI 48105.

SKINNER, THOMAS, 2002: United States Policy Committee Partners for the Great Lakes (USPC). Great Lakes Strategy 2002 - A Plan for the New Millennium. April, 2002.

SMITH L.C., TURCOTTE D.L., ISACKS B., 1998: Stream flow characterization and feature detection using a discrete wavelet transform. Hydrolog. Processes, 12, pp. 233-249.

TORRENCE C., COMPO G.P., 1998: A Practical Guide to Wavelet Analysis. Bull. Amer. Meteorolog. Soc., 79, pp. 61-78.
QIAN W., ZHU Y., LIANG J., 2004: Potantiel contribution of maximum subsurface temperature anomalies to the climate variability. Int. J. Climatol., 24, pp. 193-212.

QUINN F.H., 1981: Secular changes in annual and annual and seasonal Great Lakes precipitation. 1854-1979, and their implications for Great Lakes water resources studies. Wat. Resour. Res., 17, 6, pp. 1619-1624.

QUINN F.H. and GUERRA B.: 1986: Current perspectives on the Lake Erie water balance. J Great Lakes Res., 12, 2, pp. 109-116.

RODIONOV S.N., 1994: Association between winter precipitation and water level fluctuations in the Great Lakes and atmospheric circulation patterns. J. Climate, 7, pp. 1693$-1706$.

VENUGOPAL V., FOUFOULA-GEORGIOU E., 1996: Energy decomposition of rainfall in the time-frequency-scale domain using wavelet packets. J. Hydrol., 187, pp. 3-27.

VON STORCH H., NAVARRA A., 1995: Analysis of Climate Variability. Applications of Statistical Techniques. Springer Verlag, pp. 3-10.

Received 22. December 2009 Accepted 23. June 2010 